\title{
The relationship between attitude towards sports and bodily- kinesthetic intelligence in university students of sport science
}

\author{
Koçak Ç.V. ${ }^{1 \mathrm{ABCDE}}$ \\ ${ }^{1}$ Faculty of Sport Sciences, Department of Physical Education and Sport Education, Hitit University, Çorum, Turkey
}

Authors' Contribution: A - Study design; B - Data collection; C - Statistical analysis; D - Manuscript Preparation; E - Funds Collection.

\begin{abstract}
Purpose: $\quad$ Studies on the relationship between university students' attitudes towards sports and bodily kinesthetic intelligence have not been reached in the literature. The aim of this study was to investigate the relationship between the attitudes towards sport and bodily-kinesthetic intelligence levels of university students who studying in the sport science.

Material: $\quad$ The study group is consisted 268 [ $n=107$ - female, $n=161$ - male] students. The mean of the age of participants was 21.4 year [ \pm 3.2]. Data was collected by personal information form, Undergraduate Students' Attitudes Towards Sport Scale and the subscale of Bodily-Kinesthetic Intelligence of Multiple Intelligence Survey. SPSS 22 program was used in the analysis of the obtained data and Kolmogorov-Smirnov test was applied to determine whether the data showed normal distribution and the significance level was accepted as 0.05 in the analyses. Data were not normally distributed. Mann-Whitney $U$ test was used to analyze the data of gender and regularly exercise variable. Kruskal-Wallis test was used to analyze the age, university, department, and welfare level. Mann Whitney $\mathrm{U}$ test was used to determine the significant difference. Spearman Correlation test was applied to determine the relationship between the attitudes towards sport and bodily-kinesthetic intelligence.

Results: $\quad$ As a result of the research, a high level of significant correlation was found between attitudes towards sports and bodily-kinesthetic intelligence. Also, a significant difference was found between regularly exercise and welfare levels $[p<0.05]$. There was no significant difference in gender, age, university and department variables $[p>0.05]$.

Conclusions: The level of participating in sports and the level of welfare supports the attitude towards sports and the developing of bodily-kinesthetic intelligence. Likewise, as the attitude towards sports increases positively, bodily kinesthetic intelligence also increases positively.

Keywords: multiple intelligence, attitude, sport, athlete, university students, physical education, sport science.
\end{abstract}

\section{Introduction}

Attitude is a spiritual condition involving beliefs and emotions and is considered an important concept in understanding human behavior [1]. Our personal attitudes are directed towards our positive-negative feelings about events, people, objects or subjects that are happening around us. Attitudes occur before the behavior and direct the behavior. Attitudes cannot be observed but behavior can be evaluated and the features and characteristics of the attitude can be understood [2]. Personal attitude includes emotional and logical considerations [3].

Attitudes are formed directly or indirectly. There are two critical periods in the formation of attitudes. These are puberty [12-20 years] and first adulthood [21-30 years]. Attitudes begin to take shape in adolescence and become permanent in early adulthood. Education has a strong influence on attitudes. Effective education can change attitudes [Morgan, 1989, 4].

A sport is an indicator of the level of culture and prosperity in modern societies of our time. It is an important social phenomenon that affects all aspects of social life. [5]. Humans are the basic structure of society. Sport contributes to the physical, mental and social well-being of people [6]. According to educators, sport activities are a useful discipline that contributes to the

\footnotetext{
(c) Koçak Ç.V., 2019

doi:10.15561/20755279.2019.0306
}

positive development of personality and characteristic features. Sport is an integral part of education in the education of healthy generations and thus in the creation of contemporary societies [7].

Recognizing the importance of sport in general education, civilized countries have taken important steps in this direction and have given a great deal of importance to sports in education policies. We acknowledge this reality in Turkey in theory. However, it is an indisputable fact that we cannot fully implement it yet [8].

Nowadays, the aim of sports is similar in all societies. Sport is a part of human life by its nature. People are engaged in sports by playing games in the early stages of his/her life. Later on, he/she develops an attitude towards sports with the effect of hereditary characteristics, environment and education. This attitude determines the dimension of the relationship between people and sport throughout his/her life.

\section{Multiple Intelligence}

The person lives with his/her individual characteristics which are congenital and shaped by environmental factors in time. According Gardner [9], one of the contemporary theories emphasizing the importance of these characteristics and individual differences is the Multiple Intelligence Theory.

It is stated in the Theory of Multiple Intelligences that intelligence is only a serious mistake, measured and 
graded by IQ tests. Contrary to traditional understanding, intelligence was not a case alone and it was stated that there is a set of abilities [10]. According to Gardner [9], intelligence is an external reflection of the brain structure consisting of different parts and it is like an elastic band, and the mind consists of many intelligence fields. These areas are; Linguistic Intelligence, Bodily-Kinesthetic Intelligence, Visual Intelligence, Musical Intelligence, Logical Intelligence, Intrapersonal Intelligence, Interpersonal Intelligence, Natural Intelligence and Existential Intelligence. Armstrong [11] states that these intelligence areas are always interacting with each other. For example, a football player; he/she uses his/her physical intelligence while he/she is running or hitting he/she uses his/her visual intelligence while recognizing the field and he/she uses his/her intrapersonal intelligence while evaluating himself/herself.

Bodily-Kinesthetic Intelligence

It is the intelligence that is predominant in people who can control their bodily movements and accomplish their goals successfully. This intelligence includes skills such as coordination, dexterity, balance, flexibility, strength, speed. Athletes, actors, artists, dancers and sculptors are the people who have this intelligence. The ability to use his/her body or hands for explains one's feelings or ideas reflect this intelligence $[10,12,13]$. The bodily-kinesthetic intelligence uses the body to solve a problem, understand, or learn [14]. Many activities such as matching games, drag-and-drop exercises, or online simulations will engage this intelligence. Virtual labs will also provide hand-eye coordination and engage this intelligence [14].

Determining the dominant intelligence areas that people have is an important educational gain [15]. It is a useful teaching tool for identifying intelligence areas, meeting the needs of students, developing appropriate programs for learning styles and using activities that will enrich individuals' learning experiences [15, 16, 12].

Students use their own multi-intelligence areas to reveal their own strong abilities. It has been observed that the practices based on this theory have a positive effect on student achievement, and that the students' active participation and motivation in the courses designed according to the multiple intelligence theory has increased [17]. According to this theory, given the opportunity to use other intelligence areas as well as the dominant intelligence areas, children can also develop their weak intelligence areas [18].

The educator who prepares the activities in the education process will not serve different intelligence areas when he / she do not consider the individual characteristics. This situation will prevent the understanding of the subjects by all students and the emergence of the interests and abilities of the individuals. Failure to provide students with the opportunity to develop their abilities and intelligence will adversely affect the development. In this way, students may experience unfavorable in the future by acquiring the wrong and not suitable professions [17].

The education of individuals should be directed to prepare them for life by developing their interests and abilities, by providing them with the necessary knowledge, skills, behaviors and co-working habits and to ensure that they have a profession that will make them happy and contribute to the happiness of the society.

Considering that the attitudes occur at an early age [19], the attitude towards sports is likely to occur at an early age. Taking into account the general objectives of education, the determination of students' attitudes towards sports will allow them to be evaluated according to the multiple intelligence approach. The teacher, who knows the attitude of the student, will be able to design a training process appropriate to the interests and needs of the students. Thus, a multi-faceted development will be provided.

There are attitudes towards physical education and sports [21] in various age groups in the literature. The attitudes towards sports in the university students' sample are in the direction of scale development [22], evaluation of attitudes [23]. Although there are many studies related to multiple intelligence areas [24,25], the studies on the relationship between attitudes towards sports and multiple intelligence areas could not be reached.

The purpose of this study is investigation of the relationship between university students' attitudes towards sports with bodily-kinesthetic intelligence who studying in sport science in Turkey. The research is important in terms of innovation it brings to literature.

\section{Material and methods}

Model of the Research

Correlational survey method was used in the research. According to Fraenkel \& Wallen [26], survey methods are quantitative studies on the selected sample to describe the views or characteristics of a large community on a subject. Cohen \& Manion [27] stated that relational researches are aimed at defining and investigating human behavior in individual and social relations.

Participants:

Study group of the research formed with 268 university students [female $-\mathrm{n}=107$, male $-\mathrm{n}=161$ ] who studying sport science in The Turkey at Ankara, Gazi, Hitit and Namık Kemal Universities Faculty of Sport Science. The students sampled by convenience sampling [27, 28, 29, 30] method. The personal information of the students is presented in Table 1.

Table 1. Personal information of participants

\begin{tabular}{lll}
\hline Gender & $\mathbf{f}$ & \% \\
\hline Female & 107 & 39.9 \\
Male & 161 & 60.1 \\
Total & 268 & 100.0 \\
& & \\
\hline Age & $\mathbf{f}$ & $\%$ \\
\hline $18-20$ & 110 & 41.0 \\
$21-23$ & 116 & 43.3 \\
$24+$ & 42 & 15.7 \\
Total & 173 & 100.0 \\
\hline
\end{tabular}




\begin{tabular}{lll}
\hline University & $\mathbf{f}$ & $\mathbf{\%}$ \\
\hline Ankara & 60 & 22.4 \\
Gazi & 59 & 22.0 \\
Hitit & 91 & 34.0 \\
Namık Kemal & 58 & 21.6 \\
Total & 268 & 100.0
\end{tabular}

\begin{tabular}{lll}
\hline Department & f & \% \\
\hline $\begin{array}{l}\text { Coaching Education } \\
\text { Physical Education }\end{array}$ & 74 & 27.6 \\
$\begin{array}{l}\text { Teaching } \\
\text { Sport Management }\end{array}$ & 52 & 53.0 \\
Total & 268 & 19.4 \\
& & 100.0 \\
\hline Regularly Exercise & $\mathbf{f}$ & $\%$ \\
\hline Yes & 220 & 82.1 \\
No & 48 & 17.9 \\
Total & 268 & 100.0 \\
& & \\
\hline Welfare Level & $\mathbf{f}$ & $\%$ \\
Bad & 15 & 5.6 \\
Middle & 133 & 49.6 \\
Good & 108 & 40.3 \\
Very Good & 12 & 4.5 \\
Total & 268 & 100.0 \\
\hline
\end{tabular}

According to Table 1, the survey participants consisted of 107 female [39.9\%] and 161 male [60.1\%]. Although the percentages of the university where the participants were studying were close to each other, the highest participation was from Hitit University with $34.0 \%$ and the lowest with $22.4 \%$ was from Ankara University. The majority of the participants were $53.0 \%$ in the department of Physical Education and Sports Teaching and the second one is Coaching Education $27.6 \%$.

Procedure:

"Personal Information Form" which was created by the researcher was used in the determination of the personal information of the Students. Students attitudes towards sports were determined by Koçak's [22] University Student Attitude Scale towards Sports. The scale consists of 22 items and three sub-dimensions. The Cronbach Alpha value for the total of the scale is .89 . The bodily-kinesthetic intelligence areas of the students were determined by the sub-dimension of bodily-kinesthetic intelligence of the Multiple Intelligences Survey adapted into Turkish by Babacan \& Dilci [31]. The sub-dimension consists of 3 items and the Cronbach Alpha value for the dimension is .85 .

Statistical Analysis:

SPSS 22 program was used in the analysis of the obtained data and Kolmogorov-Smirnov test was applied to determine whether the data showed normal distribution and the significance level was accepted as 0.05 in the analyses. Data were not normally distributed. MannWhitney U test was used to analyze the data of gender and regularly exercise variable. Kruskal-Wallis test was used to analyze the age, university, department, and welfare level. LSD test was used to determine the significant difference. Spearman Correlation test was applied to determine the relationship between the attitudes towards sport and bodily-kinesthetic intelligence.

\section{Results}

Mann-Whitney U test was used to determine whether the self-efficacy of the participating differed by gender.

According to Table 2, it was determined that the differences of attitudes towards sport and bodilykinesthetic intelligence status were not statistically significant by gender variable.

Kruskal-Wallis test was used to determine whether the attitudes towards sport and bodily-kinesthetic intelligence of the participating differed by age variable.

According to Table 3, it was determined that the differences of attitudes towards sport and bodilykinesthetic intelligence status were not statistically significant by age variable.

Kruskal-Wallis test was used to determine whether the attitudes towards sport and bodily-kinesthetic intelligence of the participating differed by university variable.

According to Table 4, it was determined that the differences of attitudes towards sport and bodilykinesthetic intelligence status were not statistically significant by university variable.

Kruskal-Wallis test was used to determine whether the attitudes towards sport and bodily-kinesthetic intelligence of the participating differed by department variable.

According to Table 5, it was determined that the differences of attitudes towards sport and bodily-

Table 2. Evaluation of the students' attitudes towards sport and bodily-kinesthetic intelligence by gender.

\begin{tabular}{lllllll}
\hline Scales & Dimensions & Gender & $\mathbf{n}$ & Mean Rank & U & p \\
\hline & \multirow{2}{*}{ Psycho-social Developing } & Female & 107 & 139.59 & 7962.00 & .329 \\
& & Male & 161 & 130.26 & & \\
Attitudes & Physical Developing & Female & 107 & 139.59 & 7533.50 & .077 \\
Towards Sport & & Male & 161 & 130.26 & & \\
& & Female & 107 & 140.60 & 7961.00 & .274 \\
& Mental Developing & Male & 161 & 130.45 & & \\
Multiple & Bodily-Kinesthetic & Female & 107 & 136.65 & \multirow{2}{*}{8383.00} & .709 \\
Intelligence & Intelligence & Male & 161 & 133.07 & & \\
\hline
\end{tabular}


Table 3. Evaluation of the students' attitudes towards sport and bodily-kinesthetic intelligence by age.

\begin{tabular}{|c|c|c|c|c|c|c|c|}
\hline Scales & Dimensions & Ages & $\mathbf{n}$ & Mean Rank & $x^{2}$ & sd & $\mathbf{p}$ \\
\hline \multirow{9}{*}{$\begin{array}{l}\text { Attitudes } \\
\text { Towards } \\
\text { Sport }\end{array}$} & \multirow{4}{*}{$\begin{array}{l}\text { Psycho-social } \\
\text { Developing }\end{array}$} & $18-20$ & 110 & 135.56 & \multirow{4}{*}{.886} & \multirow{4}{*}{2} & \multirow{3}{*}{.642} \\
\hline & & $21-23$ & 116 & 136.22 & & & \\
\hline & & $24+$ & 42 & 123.82 & & & \\
\hline & & $18-20$ & 110 & 144.63 & & & \multirow{3}{*}{.149} \\
\hline & Physical & $21-23$ & 116 & 130.03 & \multirow[t]{2}{*}{3.425} & \multirow[t]{2}{*}{2} & \\
\hline & Developing & $24+$ & 42 & 120.31 & & & \\
\hline & \multirow{3}{*}{$\begin{array}{l}\text { Mental } \\
\text { Developing }\end{array}$} & $18-20$ & 110 & 134.71 & \multirow{3}{*}{15.774} & \multirow{3}{*}{2} & \multirow{3}{*}{.920} \\
\hline & & $21-23$ & 116 & 135.80 & & & \\
\hline & & $24+$ & 42 & 130.36 & & & \\
\hline \multirow{3}{*}{$\begin{array}{l}\text { Multiple } \\
\text { Intelligence }\end{array}$} & Bodily- & $18-20$ & 110 & 130.79 & \multirow{3}{*}{3.850} & \multirow{3}{*}{2} & \multirow{3}{*}{.283} \\
\hline & Kinesthetic & $21-23$ & 116 & 142.43 & & & \\
\hline & Intelligence & $24+$ & 42 & 122.33 & & & \\
\hline
\end{tabular}

$* p<0.05$

Table 4. Evaluation of the students' attitudes towards sport and bodily-kinesthetic intelligence by university.

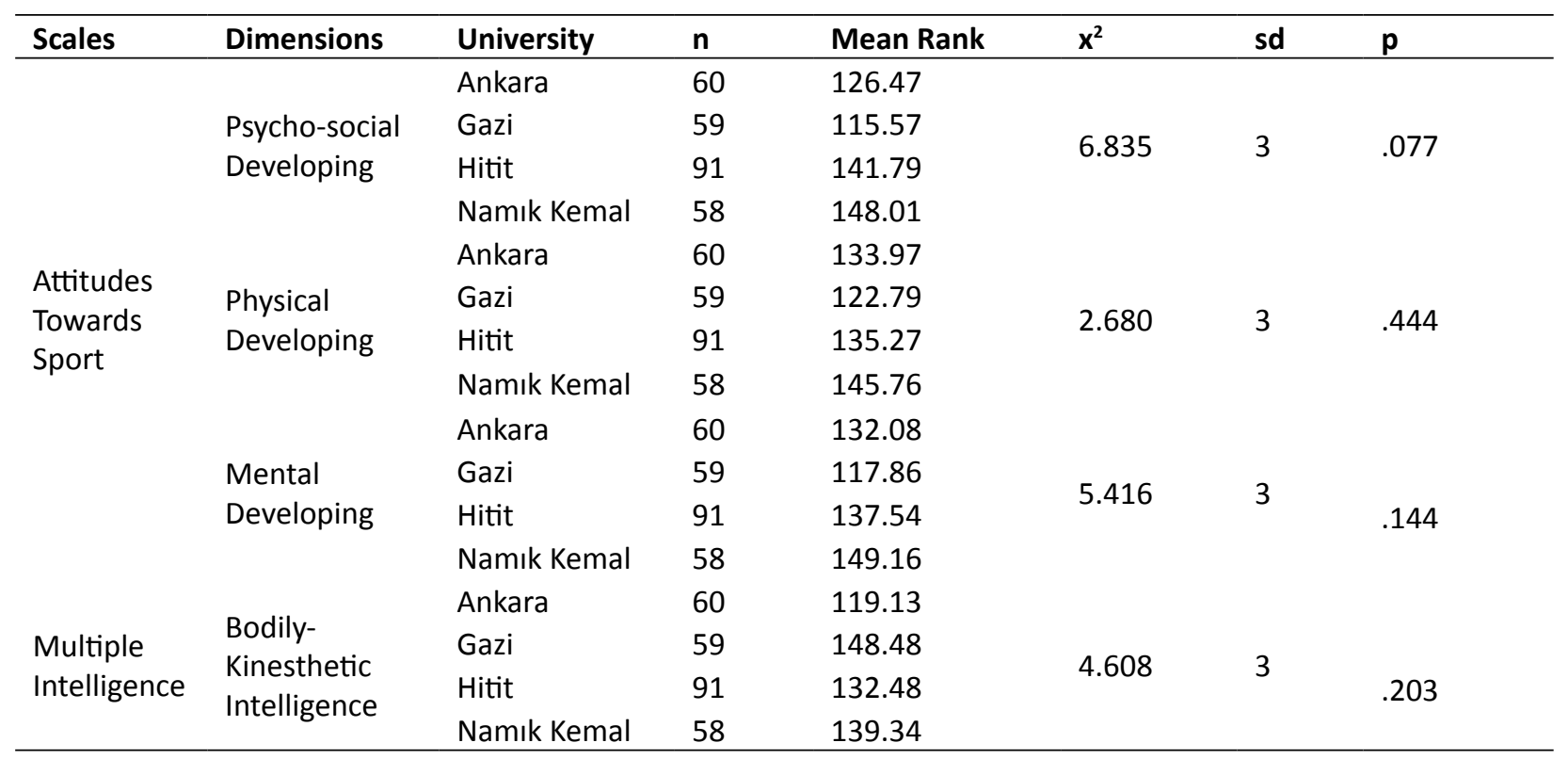

${ }^{*} p<0,05$

Table 5. Evaluation of the students' attitudes towards sport and bodily-kinesthetic intelligence by department.

\begin{tabular}{|c|c|c|c|c|c|c|c|}
\hline Scales & Dimensions & Department & & Mean Rank & $x^{2}$ & sd & $\mathbf{p}$ \\
\hline \multirow{9}{*}{$\begin{array}{l}\text { Attitudes } \\
\text { Towards } \\
\text { Sport }\end{array}$} & \multirow{3}{*}{$\begin{array}{l}\text { Psycho-social } \\
\text { Developing }\end{array}$} & Coaching Education & 74 & 126.15 & & & \\
\hline & & \multirow{2}{*}{$\begin{array}{l}\text { Physical Education } \\
\text { Sport Management }\end{array}$} & 142 & 133.45 & 2.213 & 2 & .331 \\
\hline & & & 52 & 146.67 & & & \\
\hline & \multirow{3}{*}{$\begin{array}{l}\text { Physical } \\
\text { Developing }\end{array}$} & Coaching Education & 74 & 134.95 & & & \\
\hline & & Physical Education & 142 & 133.18 & .125 & 2 & .939 \\
\hline & & Sport Management & 52 & 137.47 & & & \\
\hline & & Coaching Education & 74 & 134.45 & & & \\
\hline & Mental & Physical Education & 142 & 132.99 & .225 & 2 & .894 \\
\hline & & Sport Management & 52 & 138.70 & & & \\
\hline \multirow{3}{*}{$\begin{array}{l}\text { Multiple } \\
\text { Intelligence }\end{array}$} & Bodily- & Coaching Education & 74 & 137.57 & & & \\
\hline & Kinesthetic & Physical Education & 142 & 131.01 & .641 & 2 & .726 \\
\hline & Intelligence & Sport Management & 52 & 139.66 & & & \\
\hline
\end{tabular}

${ }^{*} p<0.05$ 
kinesthetic intelligence status were not statistically significant by department variable.

Mann-Whitney U test was used to determine whether the self-efficacy of the participating differed by exercise regularly.

Table 6 shows that there is a significant difference $[\mathrm{U}=3909.50, \mathrm{p}=.005, \mathrm{p}<0.05]$ between bodily-kinesthetic intelligence and doing regularly sports. In terms of bodilykinesthetic intelligence, the average score of the students who have regularly exercise [Mean Rank $=140.73$ ] is higher than who do not have regularly exercise [Mean Rank $=105.95]$. On the other hand, it was determined that the attitudes towards sport and bodily-kinesthetic intelligence of the participants did not differ according to the exercise regularly $[\mathrm{p}>0.05]$.

Kruskal-Wallis test was used to determine whether the attitudes towards sport and bodily-kinesthetic intelligence of the participating differed by welfare level variable.

According to Table 7, in the psycho-social developing $\left[\mathrm{X}^{2}=9.474, \mathrm{sd}=3, \mathrm{p}=.024\right]$ was found to be significantly different according to the welfare level. The Mann
Whitney U test was used to determine which group was the cause of the difference. The difference was found to be between group 2 [Mean Rank $=122.23$ ], and group 3 [Mean Rank $=144.02$ ] also between group 2 [Mean Rank $=122.23$ ] and group 4 [Mean Rank $=180.54$ ].

The difference was in the and bodily-kinesthetic intelligence $\left[X^{2}=15.233, \mathrm{sd}=3, \mathrm{p}=, 002\right]$ sub-dimension between 2nd group [Mean Rank $=121.05$ ] and 4th group [Mean Rank $=204.83$ ] also 3th group [Mean Rank = 142.06] and 4th group [Mean Rank $=204.83$ ].

Spearman Correlation test was used to evaluate the relationship between attitudes towards sport and bodilykinesthetic intelligence sub-dimensions.

According to Table 8, There is a moderate level relationship between physical kinesthetic intelligence and psychosocial development $[\mathrm{r}=313]$, a low level relationship between physical kinesthetic intelligence and physical development [ $\mathrm{r}=297]$ and a moderate level relationship between physical kinesthetic intelligence and mental development $[\mathrm{r}=314]$.

Table 6. Evaluation of the students' attitudes towards sport and bodily-kinesthetic intelligence by exercise regularly

\begin{tabular}{|c|c|c|c|c|c|c|}
\hline Scales & Dimensions & $\begin{array}{l}\text { Exercise } \\
\text { Regularly }\end{array}$ & $\mathbf{n}$ & Mean Rank & $\mathbf{U}$ & p \\
\hline \multirow{6}{*}{$\begin{array}{l}\text { Attitudes } \\
\text { Towards Sport }\end{array}$} & \multirow{2}{*}{ Psycho-social Developing } & Yes & 220 & 138.10 & \multirow{2}{*}{4359.00} & \multirow{2}{*}{.062} \\
\hline & & No & 48 & 115.31 & & \\
\hline & \multirow{2}{*}{ Physical Developing } & Yes & 220 & 137.08 & \multirow{2}{*}{4712.00} & \multirow{2}{*}{.234} \\
\hline & & No & 48 & 122.67 & & \\
\hline & \multirow{2}{*}{ Mental Developing } & Yes & 220 & 137.52 & \multirow{2}{*}{4616.00} & \multirow{2}{*}{.155} \\
\hline & & No & 48 & 120.67 & & \\
\hline \multirow{2}{*}{$\begin{array}{l}\text { Multiple } \\
\text { Intelligence }\end{array}$} & \multirow{2}{*}{$\begin{array}{l}\text { Bodily-Kinesthetic } \\
\text { Intelligence }\end{array}$} & Yes & 220 & 140.73 & \multirow{2}{*}{3909.50} & \multirow{2}{*}{$.005^{*}$} \\
\hline & & No & 48 & 105.95 & & \\
\hline
\end{tabular}

$* \mathrm{p}<0.05$

Table 7. Evaluation of the students' attitudes towards sport and bodily-kinesthetic intelligence by welfare level

\begin{tabular}{|c|c|c|c|c|c|c|c|c|}
\hline Scales & Dimensions & $\begin{array}{l}\text { Welfare } \\
\text { Level }\end{array}$ & $\mathrm{n}$ & $\begin{array}{l}\text { Mean } \\
\text { Rank }\end{array}$ & $x^{2}$ & sd & $p$ & $\mathbf{U}$ \\
\hline \multirow{12}{*}{$\begin{array}{l}\text { Attitudes } \\
\text { Towards } \\
\text { Sport }\end{array}$} & \multirow{5}{*}{$\begin{array}{l}\text { Psycho-social } \\
\text { Developing }\end{array}$} & Bad & 15 & 129.63 & \multirow{4}{*}{9.474} & \multirow{4}{*}{3} & \multirow{4}{*}{$.024 *$} & \\
\hline & & Middle & 133 & 122.23 & & & & $2<3$ \\
\hline & & Good & 108 & 144.02 & & & & $2<4$ \\
\hline & & Very Good & 12 & 180.54 & & & & \\
\hline & & Bad & 15 & 132.10 & \multirow{4}{*}{3.659} & \multirow{4}{*}{3} & \multirow{4}{*}{.301} & \\
\hline & \multirow{3}{*}{$\begin{array}{l}\text { Physical } \\
\text { Developing }\end{array}$} & Middle & 133 & 127.41 & & & & \\
\hline & & Good & 108 & 140.23 & & & & \\
\hline & & Very Good & 12 & 164.58 & & & & \\
\hline & \multirow{4}{*}{$\begin{array}{l}\text { Mental } \\
\text { Developing }\end{array}$} & Bad & 15 & 143.17 & \multirow{4}{*}{3.070} & \multirow{4}{*}{3} & \multirow{4}{*}{.381} & \\
\hline & & Middle & 133 & 129.37 & & & & \\
\hline & & Good & 108 & 136.09 & & & & \\
\hline & & Very Good & 12 & 166.25 & & & & \\
\hline \multirow{4}{*}{$\begin{array}{l}\text { Multiple } \\
\text { Intelligence }\end{array}$} & \multirow{4}{*}{$\begin{array}{l}\text { Bodily- } \\
\text { Kinesthetic } \\
\text { Intelligence }\end{array}$} & Bad & 15 & 143.03 & \multirow{4}{*}{15.233} & \multirow{4}{*}{3} & \multirow{4}{*}{$.002 *$} & \\
\hline & & Middle & 133 & 121.05 & & & & $2<4$ \\
\hline & & Good & 108 & 142.06 & & & & $3<4$ \\
\hline & & Very Good & 12 & 204.83 & & & & \\
\hline
\end{tabular}

${ }^{*} p<0.05$ 
Table 8. Evaluation of the relationship between attitudes towards sport and bodily-kinesthetic intelligence.

\begin{tabular}{lllll}
\hline Scales & Attitudes Towards Sport & $\begin{array}{l}\text { Psycho-social } \\
\text { Developing }\end{array}$ & $\begin{array}{l}\text { Physical } \\
\text { Developing }\end{array}$ & $\begin{array}{l}\text { Mental } \\
\text { Developing }\end{array}$ \\
\hline $\begin{array}{l}\text { Bodily-Kinesthetic } \\
\text { Intelligence }\end{array}$ & $\mathrm{r}$ & $.313^{* *}$ & $.297^{* *}$ & $.314^{* *}$ \\
& $\mathrm{p}$ & .000 & .000 & .000 \\
\hline
\end{tabular}

$* * p<0.01$

\section{Discussion}

In this study, the relationship between attitudes towards sport and bodily kinesthetic intelligence were examined in whom studying in the sports science area in Turkey. As a result of the study, no significant difference was found between the sub-dimensions of attitudes towards sports and physical kinesthetic intelligence among male and female students. In the literature, there are studies [22, $23,32]$ reporting that male students' attitudes towards sports are higher than female students. The reason for the differentiation of sports attitudes towards male student may be due to a cultural factor. On the other hand, there are studies [18] indicating that there is no difference between the levels of physical kinesthetic intelligence of male and female students in literature. The fact that bodily-kinesthetic intelligence does not differ according to gender in the students who study in the field of sports sciences suggests that gender is not a determinant of bodily-kinesthetic intelligence.

There was no statistically significant difference between the attitudes towards sport of the participants and their bodily-kinesthetic intelligence. There are studies [18] that support this finding in the literature.

No significant difference was found in the university and department variables. It is possible that students who are studying in the field of sports do not have a bodilykinesthetic intelligence difference with their attitudes towards sports. Because even though the sections are different, they are the sub-branches of the sports field. In the literature, there was a significant difference in the studies comparing the fields of sports sciences and other fields [25]. However, there are no studies on the comparison of different departments within the sports sciences.

There was a significant difference between the attitudes of the regular exercisers towards sports and their bodily-kinesthetic intelligence. Students who do exercise regularly have a significantly higher attitude towards sports than other students. Similarly, bodily-kinesthetic intelligence levels of the students who exercise regularly are also high. There are studies [22, 33] with similar results in literature.
There is a significant difference between students' welfare levels and their attitudes towards sports and their physical kinesthetic intelligences. According to the findings, students with high level of welfare have higher attitudes towards sport than who has poor welfare. This indicates a linear relationship between sports attitudes and bodily-kinesthetic intelligence and welfare. People in developing countries such as Turkey, they need to be able to make a good income for activities such as sports. This situation may have led to the development of attitudes towards sports and physical kinesthetic intelligence. There are studies $[22,33]$ with similar results in literature.

\section{Conclusion}

According to the results of the correlation analysis performed to reveal the primary purpose of this research, a positive correlation was found between the attitudes towards sports and bodily-kinesthetic intelligence. This result shows that as the bodily-kinesthetic intelligence increases, the attitude towards sports increases in a positive way. Studies on the relationship between towards attitudes sports and bodily-kinesthetic intelligence have not been reached in the literature. The lack of these studies makes it difficult to compare the results of the study with the literature.

As a result, it can be said that attitudes towards sports and bodily-kinesthetic intelligence affect each other positively. Therefore, multiple intelligence practices and studies to support the attitude towards sports should be included in the training programs. It is observed that the welfare level directly affects the attitudes towards sports and bodily-kinesthetic intelligence. From this point of view, it should be ensured that sport is accessible for all sections of society. Studies on the relationship between sports attitudes and physical bodily-intelligence have not been reached in the Literature. This research should be repeated with different variables, limitations and samples.

\section{Conflict of interest}

There were no conflicts of interest. 


\section{References}

1. Latchanna G, Dagnew A. Attitude of teachers towards the use of active learning methods. E-journal of All India Association for Educational Research, [Internet]. 2009 [cited 2019 Apr 02]; 21(1). Available from: https://pdfs.semanticscholar.org/ 3b12/38ab4320fa08afc02aafae140179566e14a1.pdf

2. Kalkan A. The effect of personal attitude subjective norm and perceived behavioral control on entrepreneurial intention: an application on university students. Journal of Süleyman Demirel University Institute of Social Science, [Internet]. 2011 [cited 2019 Apr 02]; 13: 189-206. Available from: http://sbedergi.sdu.edu.tr/assets/uploads/sites/343/files/ adnan-kalkan-27022013.pdf

3. Liñán F, Chen YW. Development and cross cultural application of a specific instrument to measure entrepreneurial intentions. Entrepreneurship theory and practice, 2009; 33(3): 593-617. https://doi.org/10.1111/j.1540-6520.2009.00318.x

4. Morgan CT. Psikolojiye Giriş [Introduction to Psychology]. Ankara: Turkey, H.Ü. Psychology Publishing; 1989. (In Turkish)

5. İmamoğlu AF. Some observations on Turkish sports towards two thousand years. Gazi Üniversity Gazi Journal of Gazi Educational Faculty, 1992; 8(1): 9-19.

6. Armstrong N, Welsman JR, Kirby BJ. Peak oxygen uptake and maturation in 12-yr olds. Medicine and science in sports and exercise, 1998; 30(1): 165-169. https://doi.org/10.1097/00005768-199801000-00023

7. Yetim A. Social aspects of sport. Gazi Journal of Physical Education and Sport Sciences, 2000; 5(1): 63-72.

8. Ateş M. Democracy and sport education. Dokuz Eylül University, Buca Faculty of Education Journal, [Internet]. 1992 [cited 2019 Apr 02]; 1(33). Available from: https://dspace.deu.edu.tr/xmlui/handle/12345/666

9. Gardner HE. Intelligence reframed: Multiple intelligences for the 21st century. London: UK, Hachette; 2000.

10.Armstrong T. The multiple intelligences of reading and writing: Making the words come alive. Ascd. E-book. 2003.

11.Armstrong T. Multiple Intelligences: Seven Ways to Approach Curriculum. Educational Leadership, 1994; 52(3): 26-28.

12.Armstrong T. Multiple intelligences in the classroom. Ascd. E-book; 2009.

13.Moran S, Kornhaber M, Gardner H. Orchestrating multiple intelligences. Kaleidoscope: Contemporary and classic readings in education, [Internet]. 2006 [cited 2019 Apr 02]; 188-192. Available from: https://www.wtc.ie/images/pdf/Multiple_Intelligence/mi18. pdf

14.Zobisch P, Platine D, Swanson A. The theory of multiple intelligences and critical thinking. GLOKALde, 2015; 1 : 2-10.

15.Aminuddin H, Tajularipin S, Roselan B. Philosophical approach in Applying Multiple Intelligence in Teaching and Learning as Viewed by Malaysian School Teachers. International Journal of Business and Social Science, 2011; 2 (16): 205-210.

16.Temiz N, Kiraz E. The implications of multiple intelligences theory on literacy education at first grade. Eurasian Journal of Educational Research [EJER], [Internet]. 2007 [cited 2019 Apr 02]; 27. Available from: ht tp://eds.a.ebscohost.com/eds/detail/ detail?vid=2\&sid=f2731eec-4740-4a 7 f-95c 3 $871221 \mathrm{bd003d} \% 40$ sdc-v-sessmgr05\&bdata $=$ Jmxhbmc9dH Imc210ZT11ZHMtbG12ZQ\%3d\%3d\#AN=25641777\&db=e do
17.Campbell B. Multiple intelligences in action. Childhood Education, 1992; 68(4), 197-201. https://doi.org/10.1080/00094056.1992.10520874

18.Baba Kaya H, Karakaş G, Gizdem S. Examining the relationship between physical/kinesthetic intelligence and academic successes of physical education and sport students. CBU Journal of Physical Education and Sport Sciences, 2015; 10(1): 66-74.

19.Tavşancıl E, Keser H. Development of likert type attitude scale towards internet. Ankara University Journal of Faculty of Educational Sciences, 2001; 34(1): 45-60. https://dx.doi.org/10.1501/Egifak_0000000043

20.Keskin N, Öncü E, Küçük KS. Attitudes and self-efficacy of middle school students toward physical education classes. Spormetre the Journal of Physical Education and Sport Sciences, 2016; 14(1): 93-107.

21.Akandere M, Özyalvaç NT, Duman S. The attitudes of the students in secondary education to physical education lesson and the investigation of their success motivations [konya anatolian high school sample]. Selçuk University, Journal of Social Sciences Institute, 2010; 24: 1-10.

22.Koçak F. Undergraduate students's attitudes towards sport: A Scale development study. SPORMETRE Beden Eğitimi ve Spor Bilimleri Dergisi, 2014; 12(1): 59-69. https://doi.org/10.1501/Sporm_0000000254

23.Türkmen M, Abdurahimoğlu Y, Varol S, Gökdağ M. The attitudes of the students attending to faculty of islamic sciences towards sports [The sample of Bartın University]. International Journal of Contemporary Educational Studies [IntJCES], 2016; 2(1): 48-59.

24.Aslan CS, Dalkiran O, Özer U. Investigation of athletes' multiple intelligence domains doing cyclic and acyclic sports: a pilot study. International Journal of Contemporary Educational Studies [IntJCES], 2015; 1(1): 26-33.

25.Kahraman Dİ, Bavlı Ö. Investigation the multiple intelligence areas of university students who study in different departments. International Journal of New Trends in Arts, Sports \& Science Education [IJTASE], 2014; 3(3): 65-71.

26.Fraenkel JR, Wallen NE. How to design and evaluate research in education. New York: USA, Mc Grawall Hill; 2006.

27.Cohen LM, Manion L. Research Methods in Education. New York: USA, Routledge; 1998.

28.BüyüköztürkŞ,ÇakmakEK.,AkgünÖE,KaradenizŞ,Demirel, F. Scientific research methods. Pegem Atıfindeksi, 2017;1-360. https://doi.org/10.14527/9789944919289

29.Koçak F. The relationship between leisure constraints, constraint negotiation strategies and facilitators with recreational sport activity participation of college students. College Student Journal, 2017a; 51(4): 491-497.

30.Koçak F. Leisure constraints and facilitators: Perspectives from Turkey. European Journal of Physical Education and Sport Science, 2017b; 3(10): 32-47. https://doi.org/10.5281/zenodo.852540

31.Babacan T, Dilci T. Adaptation of multiple intelligence survey in to Turkish. NWSA-Education Sciences, 2012; 7(3): 969-982.

32.Tomik R, Olex-Zarychta D, Mynarski W. Social values of sport participation and their significance for youth attitudes towards physical education and sport. Studies in Physical Culture and Tourism, 2012; 19(2): 99-104.

33.Singh RC, Devi KS. Attitude of higher secondary level student towards games and sports. International Journal of Physical Education, Fitness and Sports, 2013; 2(4): 80-85. https://doi.org/10.26524/13421 


\section{Information about the author:}

Koçak Ç.V.; http://orcid.org/0000-0002-1403-0812; velikocak@hitit.edu.tr; Faculty of Sport Sciences, Department of Physical Education and Sport Education, Hitit University; Kuzey Kampüsü, Çevreyolu Bulvarı, 19100, Çorum, Turkey.

\section{Cite this article as:}

Koçak ÇV. The relationship between attitude towards sports and bodily-kinesthetic intelligence in university students of sport science. Physical education of students, 2019;23(3):147-154.

https://doi.org/10.15561/20755279.2019.0306

This is an Open Access article distributed under the terms of the Creative Commons Attribution License, which permits unrestricted use, distribution, and reproduction in any medium, provided the original work is properly cited http://creativecommons.org/licenses/by/4.0/deed.en

Received: 10.04.2019

Accepted: 07.05.2019; Published: 28.06.2019 